\title{
Media Relations Video Learning and Motivation to Learn The Skills of Writing Poetry In Class X high School Private Bodhicitta Medan The Academic Year 2021/2022
}

\author{
Sukawi \\ Sekolah Pascasarjana Universitas Prima Indonesia Medan \\ *Coresponding Author \\ Email : bhikkhu.dhira@gmail.com
}

\begin{abstract}
This study aims to determine the relationship of instructional media fucking with the skills to write poetry, the relationship of motivation to learn the skills of writing poetry, and determine the relationship of media video learning and motivation learning together with writing skills of the poetry of the students of class X Private high school Bodhicitta Medan academic year 2021/2022. This research was conducted in SMA SwastaBodhicitta Terrain of Class $X$ of a population of 78 people, and the number of samples is overall the students of class $X$ amount to 78 students with the use of quantitative methods as well as data obtained using the instrument questionnaire and documentation. Data analysis using the $t$ test ( $t$-test) for the correlation sderhana and the $F$ test (F-test) for the multiple correlation. These findings indicate: 1$)$. The $t$ value to the variable $(X 1)$ with $(Y)=$ $0,012$ with the $t$ table at a significance level of $5 \%=1,984.2)$. The $t$ value to the variable $(X 2)$ with $(Y)=1,259$ with the $t$ table at a significance level of $5 \%=1,984.3)$. Calculated $F$ value for the variable (X1) and (X2) together with $(Y)=1,09$ with the F table at the significance level of 5\%=3,087. The conclusion of this study explain that the absence of a positive relationship and significant correlation between learning media fucking with the skills to write poetry students and the absence of a positive relationship and significant correlation between learning motivation with the skills to write poetry students, as well as the absence of a positive relationship and significant between media video learning and motivation to learn the skills of writing poetry class X Private high school Bodhicitta Medan academic Year 2021/2022.
\end{abstract}

Keywords: Skills Of Writing Poetry, Learning Media Vidio, Motivation To Learn

\section{INTRODUCTION}

In the 2013 Curriculum, the skills of writing poetry on the level of high SCHOOL education is a basic competence (KD 4.17) that must be owned by the students. In the curriculum, learning to write poetry is a part of Indonesian language learning. In learning to write poetry in accordance with the curriculum must pay attention to the construction of the writing of the poem itself, such as: theme, diction, style, language, imagination, structure, and appearance.

According to (Fasisal, et al 2020) the Skills of writing his own poems included in the category of literary writing, because the main characteristic of writing poetry there is in the imagination that is used to generate a beautiful masterpiece with the attention to elements of poetry. Poetry is one form of literary works that are embodied with beautiful words and meaningful depth (Wahyuni, 2014), the Poem can be interpreted as a language of feelings that can synthesize a response deep in a few words. The poem basically is a genre of literature that is distinctive and unique. The peculiarities of the poem lies in, including solid word, solid meaning, one has a double meaning, rhythmic, bermajas or stylized language (Hidayah,2019).

Therefore, writing poetry requires a skill of its own. Writing poetry is one way to pour ideas, imagination and other things related to writing. According to Sulkifli \& Mawarti, writing is the process of changing thoughts, fancies, feelings into the form of the emblem, sign, writing 
Volume 1, Number 4, February 2022, Page. 426 - 435

Email : editorijhess@gmail.com

a meaningful (Sulkifli and Marwan. 2016), Write poetry-do not close the possibility of writing skills of the other-is the process of thinking carefully, writing can also be likened to the art of craft (craft) are continuously trained so as to facilitate the author to "play" the words, the meaning, language, values, and viewpoints (Sardila, V. 2015)

The poem became an attraction for the readers, because the poem has a touch so soft. So that the reader "can't say" when reading one of poems especially pusi themed sad, poetry mother, a love poem. One of the roles of the poem that the poem encourages readers to think more deeply of the meaning of the pisi contained in it, the poem is able to give a sense of fun and cool poem can train the imagination of the reader or the author of the poem itself.

Therefore, learning to write poetry as a basic competency for students is an attempt to improve the imagination, improve the creativity and productivity of the students (Satinem, J. 2018). In addition, learning to write poetry is done with the aim to improve the ability of students in the pouring of the reality of life in the community through the language of the beautiful and attractive. The competence of the writing of the poem are not only beneficial to improve the ability to speak, but also add to and enrich the knowledge as well as the personality of the students (Taum, Yoseph Yapi. 2017).

The literary form of poetry is one of the important aspects in this life. Literature can be in the form of observations through the eyes of the author. Through literature, we can understand many things about human life. Author literature generally observe a variety of life issues as well as issues that exist in society which they then pour in the writing of literature both in the form of poetry. Literature in the past is also one of the ways of delivering advice and moral messages that aims to teach about the meaning of life and how to be a better human being.

Literature is an important aspect in various fields of human life. Without literature then the person will not understand or could just forget about the culture and traditions of the ancestors or the ancestors. Through the literature also, a person is able to express himself with the writings and literature are also able to make someone become more critical because the literature is able to make someone become more knowledgeable and have a better understanding about everything.

But in fact, the skill of writing poetry for high SCHOOL students is still considered difficult by the students (Rahayu, E., Rohmadi, M., Andayani, A. 2018), this is because for writing poetry, students must first be able to identify and analyze the elements of the development of writing poems that are difficult to understand, which is the theme, atmosphere, melody, song, rima, and the use of diction/vocabulary requires an understanding of the high (Faisal, A.H., Zuriyati, Leiliyanti, E. 2020).

Again, according to Kibtiyah and Abbas, is still difficult students write poetry because faktro other that influence it, namely how to teach teachers using conventional methods. So the process of learning to write poetry impressed boring and students just receive learning passively (Kibtiyah, A. M., Abbas, N. 2014). As a result, it is still difficult students write a poem impact to not able students give birth to works of poetry. This then also have an impact on their interest to write and also read the results of the work of poetry that have been there.

Based on the observation that little is done to a high SCHOOL Bodhicitha Terrain, this school has a lot of learning facilities in the form of facilities and infrastructure sufficient and more than enough, which can trigger students ' motivation is high enough, so that the students can have skills in the areas of lesson that taught the teacher in class including the skill of writing poetry. But based on interviews with teachers of Indonesian language subjects in high SCHOOL Bodhichitta Terrain, the skill of writing poetry students can be categorized many who get a low enough value, it will surely be a gap. Should schools have facilities and infrastructure very adequate can be directly proportional to the level of skills possessed by the students. Most likely among the factors the cause of this gap is the motivation of students in the 
Volume 1, Number 4, February 2022, Page. 426 - 435

Email : editorijhess@gmail.com

following subjects Indonesian language is weak and also the use of learning media that are less good. If the media used the teacher in teaching it can attract students ' attention, then will arise the spirit of learning that will encourage thinking ability of students to understand and analyse the material given to the students.

A lot of the learning media that can be used in teaching learning process, however, in this study the authors chose learning media with fucking audio visual to see the level of ability to write poetry. Media video audio visual consist of in terms of vision and hearing, can help students gain knowledge, theme, mood, melody, song, rima, and the use of diction/vocabulary in writing poetry (Syarwah, R.A., Fauziddin, M., Hidayat, A. 2019). In addition, by using the media vidio audio visual can help teachers convey the material and used to excite the imagination of students. So that students can pour his ideas into a series of beautiful words in writing poetry (Hermawan, I. J. 2017).

The use of media vidio audio-visual learning in the writing of poetry is a form of utilization of the potential of the development of technology. So the use of media vidio audio visual is expected to create media learning engaging, effective, and efficient. This is in accordance with the Regulation of the Minister of Education and Culture Republic of Indonesia No. 22 2016, to realize the learning process interactive, fun, motivating, and increase the participation of learners, teachers are expected to utilize a variety of media for learning resources so that potential students can be developed to the maximum.

What's more, the conditions of the pandemic Covid-19 as it currently requires that the learning process is done online (online) by using various app-based online. So, according to the researchers, learning to write poetry for students faced on a "job" which is heavy and difficult. In this context, important for teachers to develop learning media effective and efficient with the use of technology, particularly in the learning of writing.

The selection of learning media right on the pandemic of Covid-19 is an important thing to consider. With the learning media then the learners are helped to understand the learning materials provided, although students learn in each house. Learning Media can also be customized with the characteristics of the learners and the ability of learners in the use of such media (Ahmadi,et,al, 2017). Learning by using video media considered appropriate for the current pandemic of Covid-19 because it is easy to use and can be followed by all students (Susmiati, E, 2020). In addition, during the pandemic teacher can not meet the learners directly, then media video learning is considered to be appropriate to facilitate the teacher explains the learning materials(Atsani, 2020). Then, the learning media videos also considered to cope with boredom and saturation of the learners while studying at home. Hadi, 2017).

By because of the many advantages of the use of learning media videos during the pendemi Covid-19, then a lot of educators who apply this media on learning activities in the classroom. Support the use of technology in the form of video audio visual in learning not only facilitate the learners in understanding the learning materials in the writing of poetry. But more than that, the use of technology can encourage learners to be more motivated, active and contributive in the learning process, especially the material about the writing of poetry.

In addition, the students today are very "literate" and open to the development of technology, so is able to utilize technology in the form of video audio visual to improve the ability and pemahamaannya about writing poetry. This is the great potential that can be used by teachers to create media and learning methods that are targeted effectively and efficiently.

By utilizing the learning media in the form of video (moving pictures) and audio (sound) as source of inspiration for poetry writing, it is expected that students will more easily form the thought and then poured it (write it down) in the literary works of poetry as expected. In addition, it is expected the learning process can be fun, motivating, focused, and increase participation and the ability of students in writing a literary works of poetry (Abduh, N. K. 2018). 


\section{RESEARCH METHODS}

The research method used in this research is quantitative method with the calculation of the data obtained from pesebaran of the instruments used. It Suharsimi Arikunto (2009: 247) states that research is a correlation research is intended to determine whether there is a relationship between two or more variables. The selection method is based on the desire to get an overview about the use of media video learning and learning motivation toward the skills of writing poetry student at the Private high SCHOOL Bodhicitta Terrain as well as a conjunction, either directly or indirectly from the research variables.

This study of the relationship of media use video learning and motivation to learn the skills of writing poetry to students in Private high SCHOOL Bodhicitta Medan academic Year 2021/2022. Operational definition of variable in this study is:

1. For operating the media of learning (X1) is a physical transmitter of the subject matter interesting and flexible used by the teacher to deliver teaching materials with the aim that students can be stimulated to learn with serious and make an impression within the minds and hearts of students. Through the theory put forward by experts, the variable learning media can be measured through indicators: (1) the physical Tools and materials; (2) Stimulate to learn; (3) to Disseminate the material; (4) is Used for educational purposes; (5) To acquire knowledge.

2. Oprasional learning motivation (X2) is the encouragement that there is from within one's self, both from the internal and external factors that make a person want to make the process of learning as an effort to change behavior with the passion and seriousness and responsibility in menenmpuh the path of learning. Through the theory put forward by Hamzah B uno, variable motivation to learn can be measured through indicators: 1) the existence of passion and desire to succeed, 2) the encouragement and the needs in learning, 3) the presence of the hopes and ideals of the future, 4) the award in learning, 5) the presence of interesting activities in learning, 6) the presence of a conducive learning environment, allowing someone the students can learn well.

In operational Skills of writing poetry $(\mathrm{Y})$ is basically the skill in summarizing or arrange the words so that it becomes a coherent whole. According to Suryaman (2005:20) a poem is a work of emotion, imagination, thoughts, ideas, notes, the rhythm, the impression of the senses, the arrangement of words, figures of speech, density, and a mixed feeling with the attention of the reader.

Figur 1. Conceptual Framework Research 


\section{Research Instruments}

In this research, a tool designed specifically to obtain data and information about the object of research used instrument in the form of questionnaires. A questionnaire is prepared and designed in such a way and used to measure the use of the media vidio, motivation to learn and the skills of writing poetry students.

\section{Test Instruments}

Before the use of the instrument conducted the first trials to get the instrument a valid and hadal (valid and reliable). The validity of which is to see how far of a measuring instrument is able to measure what should be measured and the reliability (terhadalan), namely the extent of a measuring device is able to provide consistent measurement results in different times and places. The procedure of the trial implementation of the instrument are: (1) the determination of the respondent trial; (2) the implementation of the trial; (3) analysis of the trial. Respondents trials were taken from the population beyond the sample has been determined. Number of all respondents trials will be taken adequately. The test instrument is held against the use of learning media fucking that exist in the population as many as 30 people but not selected as the research sample (out of sample). Data analysis the test results are intended to obtain batir-item instruments that meet the requirements so it is worth used as a measuring tool in collecting data.

\section{Test the validity of instruments (validity)}

The validity of the instrument intended to determine the level of accuracy of the instruments used. The development of instruments to get instruyen a valid conducted with the use of the validity of the content (content validity), and validity (construct validity). In the implementation, in the search for internal consistency and discard the grains statement weak, 
Email : editorijhess@gmail.com

then ask for the consideration of the supervisor so that the obtained batir-item questionnaire that good and qualified. The preparation of the questionnaire dilakukakan to consider the following matters: (1) avoid questions that are dubious or unclear; (2) avoid the use of words that may cause suspicion and antipathy; (3) waived the use of the word which is the key or point to one of the choice of answers and respondents. The instrument has been tested and processed and analyzed using the technique of correlation Product Moment by the Person

\section{Data Analysis Techniques}

Analysis of the data in question is to process the data obtained from the results of research to determine whether or not the correlation between each variable that can be accounted for and trusted kebenarannyasecara objective, then with this, researchers analyzed using the formula with the help of SPSS software and Microsoft Excel.

Data analysis is intended to test hypotheses that have been proposed. Therefore, the instrument that was given to respondents in the form of the scale range or interval, then the data analysis techniques used for the purpose of these is to inferential statistics i.e. with the (statistical parametric), starting from the assumption that the data obtained are normal and homogeneous then to test the hypothesis is multiple correlation. Data analysis techniques include test requirements of data analysis as a prerequisite for the use of the techniques of analysis, and hypothesis test.

\section{Research Hypothesis}

A hypothesis is a statement a while, that the value of the truth is still weak and need to be verified. The truth of the hypothesis that appear should be tested for its existence with the data in the field. The hypothesis of this research, as follows:

1) The First Hypothesis

$\mathrm{Ho}=$ there is No significant relationship between the motivation to learn by using learning media vidio

$\mathrm{Ha}=$ There is a significant relationship between motivation to learn by using learning media vidio

2) The Second Hypothesis

Ho $=$ there is No significant relationship between the skill to write poetry with the use of learning media vidio.

$\mathrm{Ha}=$ There is a significant relationship between the skill to write poetry using the learning media vidio.

3) The Third Hypothesis

$\mathrm{Ho}=$ there is No significant relationship between learning motivation and the skill to write poetry simultaneously by using learning media vidio.

$\mathrm{Ha}=$ There is a significant relationship between motivation to learn and the skills of writing poetry simultaneously by using learning media vidio.

\section{RESULTS AND DISCUSSION}

The relationship Between Learning Media fucking with the skills to write Poetry Students

The results of this study also show that there is a positive relationship and significant correlation between Learning Media fucking (X1) with the skills to write poetry students (Y). 
Email : editorijhess@gmail.com

From the results of the analysis using Product Moment correlation obtained coefficient $r$ count of 0,124 . Koefisisen correlation between the media of learning and learning outcomes in mathematics trigonmetri these students actually have a relationship as well as learning motivation and learning outcomes natenatika trigonmetri students, but with the weak, as evidenced by the value of the correlation coefficient is almost close to zero makes the value of koefisisen correlation can be ignored or interpreted that there is no relationship between media and learning Skills of writing poetry students in the area of the sample. Therefore, when in the test sgnifikansi to analyze the applicability of the correlation to the population cause the results of the $\mathrm{t}$ with the value of 1,259 the results are Then consulted with the $t$ table at a significance level of $5 \%$ to test the significance level of the correlation. The price of the correlation coefficient $r$ table at a significance level of 5\% and $\mathrm{N}=104$ is 1.984 . These results indicate that there is a positive relationship and significant correlation between learning media fucking and skills of writing poetry students. These findings are also not in line with the opinion of the Mudhoffir which states that the learning media as a source of learning is a component of the learning system that has a relationship and can affect the learning outcomes of students. So if the media-based learning vidio designed and given to students with good it can't certainly be able to acquire the skills of writing poetry students are also high. It is thus, therefore $\mathrm{H} 0$ is accepted, and Ha is rejected.

\section{The relationship of Motivation to Learn the Skills of writing poetry Students}

The results of this study show that there is a positive relationship and significant correlation between learning motivation (X2) with the skills to write poetry students (Y). From the results of the analysis using Product Moment correlation obtained coefficient $r$ count of 0.001 . Koefisisen the correlation between $\mathrm{X} 1$ and $\mathrm{Y}$ is actually have a relationship, but with the very weak, as evidenced by the value of the correlation coefficient is almost close to zero makes the value of koefisisen correlation can be ignored or interpreted that there is no relationship between the $\mathrm{X} 2$ with $\mathrm{Y}$ in the area of the sample. Therefore, when in the test sgnifikansi to analyze the applicability of the correlation to the population cause the results of the $t$ with a value of 0.012 which the results are then consulted with the $t$ table at a significance level of $5 \%$ to test the significance level of the correlation. The price of the correlation coefficient on the t table with a significance level of $5 \%$ and $\mathrm{N}=104$ is 1.984 . These results indicate that there is a positive relationship and significant correlation between learning motivation with the skills to write poetry students because the value of $t$ count is small when compared with the value of $t$ table. These findings are not appropriate and not in line with the rule of law correlation proposed by Syafi' about the relationship between the variables of learning motivation with learning outcomes. He stated that the one who has a relationship with the learning outcomes and can give the influence of it is the motivation of learning for students a structured and terkonstruk well. Then the conceptual framework proposed by the researcher is not in accordance with the findings expected. This study is also not relevant to the results obtained by other researchers. Therefore $\mathrm{HO}$ is accepted, then directly that $\mathrm{Ha}$ is rejected. So if the students motivation to learn is high or low then it will not obtain the results of the study on the material of poetry that high anyway.

\section{The relationship Between Learning Motivation and Learning Media vidio Together with the Skills of Writing Poetry Students}

The results of this study show that there is a positive relationship and significant correlation between learning media fucking (X1) and learning motivation (X2) together with the skills of writing poetry Students (Y) the class X Private high school Bodhicitta Medan academic Year 2021/2022. 
Volume 1, Number 4, February 2022, Page. 426 - 435

Email : editorijhess@gmail.com

Based on the results of the analysis through Microsoft Excel using the analysis of the multiple correlation coefficient values obtained correlation of content 0,141 which indicates that the relationship between the variables learning media vidio motivation and learning together with writing skills of the poetry of the students on the material of the poem is very weak. Through the koefisisen multiple correlation is that then substitute into the formula F count, then got the value of $\mathrm{F}$ count equal to 1,029 and $\mathrm{F}$ table at a significance level of $5 \%$ is $\$ 3,087$. Price calculated $\mathrm{F}$ is less than $\mathrm{F}$ table at a significance level of 5\%. This means that all three of these variables have no significant relationship, namely between media video learning and motivation learning together with writing skills of poetry students. These findings are also contrary to the opinion of the Shafi'i and Mudhoffir stating that the media of learning and motivation to learn has a relationship with the learning outcomes and can affect the skills possessed students.

Based on the results of the analysis of multiple correlation in the above, it can be informed that the third hypothesis that is submitted is also rejected, or in other words, accept $\mathrm{HO}$ and $\mathrm{Ha}$ is rejected, shown by the calculated $\mathrm{F}$ is less than $\mathrm{F}$ table. The results of this study are not in accordance with the results of previous research which shows that students ' motivation and learning media together have a positive and significant relationship with the results of the learn English material poetry at the Private high school Bodhicitta Terrain class X.

Through the results of this study can also be informed that, any form of business motivation which is done through external and internal factors to the students to increase the desire in learning the material of the poem, will not be able to make sure that it can improve the skills of writing poetry student at the Private high SCHOOL Bodhicitta Terrain Class X. So is the case with the media of learning given by the teacher, although learning media such as video has been designed by teachers to teach the material of the poem, then it also does not guarantee that students are able to receive the subject matter well and understand it. A class X student at the Private high school Bodhicitta Medan, still assume that the material of poetry is a difficult thing and the Indonesian lessons. This opinion appears because of the lack of teachers who are able to change the mindset of students towards how to teach poetry fun in class X Private high school Bodhicitta Terrain. However, it does not apply to all students in the class X Private high school Bodhicitta Terrain, because there are some students who are able to get a perfect score, i.e. 100. This can be seen in appendix 3 about the value of learning outcomes in the material of poetry.

Although only a small fraction of the entire sample which is about 10.1 percent, but it is very possible to show that media-based learning vidio and motivation to learn has a relationship that is very small with keterampian write a poem students in class X Private high school Bodhicitta Medan academic Year 2021/2022, proven by the correlation coefficient indicated by the correlation table in the analysis of the above data. The results of this study are also very much in line with the statement given by some students when interviewed in nonformal. They said that although it has a high learning motivation and taught through mediabased learning vidio, then it is not necessarily can make students to understand the material of poetry, and they also mngakui that the material of this poem is a material that is difficult to understand.

\section{CONCLUSION}

Based on the results of research on the relationship between media video learning and motivation to learn the skills of writing poetry students in Indonesian language subjects the material of the poem, it can be concluded that the:

1. Media-based learning videos with the skills to write poetry students, also does not have a positive relationship and significant correlation between learning media fucking with the skills to write poetry students in class X SMA Bodhicitta Medan academic 
Email : editorijhess@gmail.com

year 2021/2022 proven with the demonstrated value of the correlation coefficient which is equal to 0,124 that shows the very weak and continued with the value of $t$ count is less than the value $t$ table $(1,259<1,984)$.

2. Students motivation to learn the skills of writing poetry students in Indonesian language subjects on the material of the poem does not have a positive relationship and significant correlation between learning motivation with the skills of writing poetry class X high School Bodhicitta Medan academic year 2021/2022 indicated by the value of the coefficient of correlation is very weak of 0.001 , and the value of $t$ count is less than the value $t$ table $(0,012<1,984)$.

Proven with very weak value of the coefficient of multiple correlation which amounted content 0,141 with the very weak and thus affects the small value of $F$ count against the $F$ table $(1,029<3,087)$. It can be concluded that there is no positive relationship and significant between media learning videos and motivation to learn together with the skills of writing poetry class X high School Bodhicitta Medan academic year 2021/2022.

\section{REFERENCES}

Abduh, N. K. 2018, "Pemanfaatan Teknik Akrostik untuk Meningkatkan Kemampuan Menulis Puisi Siswa Kelas VIII SMP, RETORIKA: Jurnal Bahasa, Sastra dan Pengajaran, Vol. 11, No. 1: p. 40

Atsani, K. L. G. M. Z. "Transformasi Media Pembelajaran pada Masa Pandemi COVID-19”, dalam Al-Hikmah: Jurnal Studi Islam, Vol. 1, No. 1, hlm. 82-93

Faisal, A.H., Zuriyati, Leiliyanti, E. 2020. "Media Pembelajaran Menulis Puisi Berbasis Aplikasi Android Untuk Siswa SMA”, Jurnal Teknologi Pendidikan, Vol. 08, No. 1.

Hermawan, I. J. 2017. "Peningkatan Kemampuan Menulis Puisi dengan Mengunakan Media Audio Visual, Jurnal Diksatrasia, Vol. 1. No. 1: p. 39-45

Hidayah, R.S.,Darmuki, A., Hasanudin, C. 2019. "Peningkatan Keterampilan Menulis Puisi dengan Menggunakan Metode Quantum Learning dan Media Vidio pada Siswa Kelas X IPA I SMA Negeri 2 Blora Tahun Ajaran 2018/2019, Jurnalistrendi: Jurnal Linguistik, Sastra, dan Pendidikan, Vol. 4, No. 1: p. 310.

Sardila, V. 2015. "Strategi Pengembangan Linguistik Terapan Melalui Kemampuan Menulis Biografi dan Autobiografi: Sebuah Upaya Membangun Keterampilan Menulis Kreatif Mahasiswa, Jurnal Pemikiran Islam, Vol. 40. No. 2: p. 112.

Satinem, J. 2018. "Development of Teaching Materials of Poetry Writing Using Pictures for the Elementari Students, AIAC, Vol. 9, No. 3.

Sulkifli dan Marwan. 2016. "Kemampuan Menulis Puisi Kelas VIII SMP Negeri Satu Atap 3 Langi Kimia Kabupaten Konawe Utara”, Jurnal Bastra, Vol. 1, No. 1: p. 1-3 
Syarwah, R.A., Fauziddin, M., Hidayat, A. 2019. "Peningkatan Motivasi Belajar Siswa Menggunakan Media Audio Visual Pada Pembelajaran Bahasa Indonsia, Jurnal Pendidikan Tambusai, Vol. 2. No. 5: p. 936

Taum, Yoseph Yapi. 2017. "Pemebelajaran Sastra Berbasis Teks: Peluang dan Tantangan Kurikulum 2013, Jurnal Ilmiah Kebudayaan: SINTESIS, Vol. 11, No. 1

Wahyuni, R. Kitab Lengkap Puisi, Prosa, dan Pantun Lama, Yogyakarta: Saufa. 2014 Hadi, S. "Efektivitas penggunaan video sebagai media pembelajaran untuk siswa sekolah dasar". In Seminar Nasional Teknologi Pembelajaran Dan Pendidikan Dasar 2017, hlm. 96-102 